\title{
Maximizing Mudharabah Savings and Mudharabah Deposits against Mudharabah Financing Sharia of Commercial Bank
}

\author{
Prianda Pebri' ${ }^{1}$, Surya Bakti ${ }^{2}$ \\ ${ }^{1,2}$ STIE STIE Muhammadiyah Asahan, Indonesia \\ prianda.pebri89@gmail.com
}

\begin{abstract}
The purpose of this study is to partially and simultaneously determine the effect of mudharabah savings and mudharabah deposits on mudharabah financing at Commercial Sharia Bank. It is quantitative reserach. The population in this study is the Statistics of Sharia Banks (SPS), which includes statistics on mudharabah savings, mudharabah deposits, and mudharabah financing for Sharia Commercial Banks from January 2015 to December 2019 which comes from the Statistics of Sharia Banks (SPS). This data is obtained from Financial Services Authority website with link www.ojk.go.id. which is published monthly. Data analysis is using multiple linear regression analysis. The results show as partially, it is only mudharabah savings have a positive and significant effect on mudharabah financing for Sharia Commercial Banks. While mudharabah deposits have no effect on the mudharabah financing of Sharia Commercial Banks. Furthermore, simultaneously the two independent variables, which are mudharabah savings and mudharabah deposits have a positive and significant effect on mudharabah financing for Sharia Commercial Banks.
\end{abstract}

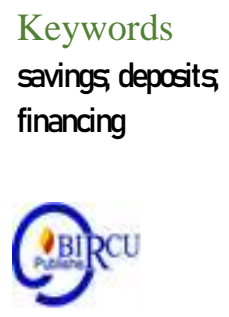

Keywords

savings, deposits,

financing

\section{Introduction}

At this time, there is a dual banking system in Indonesia, namely conventional banks that apply the interest system and Sharia banks that apply the Islamic Law system such as mudharabah, musyarakah, murabahah, and other contracts. There are three business activities of banks, they are collecting funds from the public, distributing funds to the public, and services. Distribution of funds in Sharia banks is called financing.

Every business activity carried out by the community certainly needs financial assistance in developing the business they have. Mudharabah financing can be one way out to get capital assistance from Sharia banks. Sharia banks act as owners of capital and customers act as capital managers by contributing the skills they have in developing these business activities. The profits obtained are shared according to the agreement between the Sharia Bank and the customer.

Some important notes for the development Sharia Bank especially mudharabah financing are customers who have problems in paying installments to the bank and frequent show non-performing loans (Non-Performing Financing). Some customers are also often dishonest in conveying the benefits obtained, of course this is not good or give no benefit to the Sharia Bank. At this time, Sharia banks are more selective in providing financing, especially mudharabah financing to customers, this is done to minimize problematic financing. Sharia Commercial Bank is the largest type of Sharia Bank in Indonesia. 
One of the ways to solve problematic financing problems is by obtaining sources of funds that come from the community which called Third Party Funds. Sharia Commercial Banks collect funds from the public or Third Party Funds in the form of savings, deposits and run a mudharabah or wadiah contract. These Third Party Funds for Sharia Commercial Banks are used to encounter problematic financing, especially non-performing mudharabah financing, which often occurs.

As an intermediary institution, Sharia Commercial Banks intermediary between people who have more excess funds and people who are short of funds. Fund collection products which are often used by the public at Sharia Commercial Banks are mudharabah savings and mudharabah deposits. The following is the development of mudharabah savings, mudharabah deposits, and mudharabah financing for Sharia Commercial Banks:

Table 1. Development of Mudharabah Financing, Mudharabah Savings, and Mudharabah Deposits for Sharia Commercial Banks in 2015-2019 (Billion Rupiah)

\begin{tabular}{|l|c|c|c|c|c|}
\hline \multicolumn{1}{|c|}{ Information } & $\mathbf{2 0 1 5}$ & $\mathbf{2 0 1 6}$ & $\mathbf{2 0 1 7}$ & $\mathbf{2 0 1 8}$ & $\mathbf{2 0 1 9}$ \\
\hline Mudharabah Financing & 7.979 & 7.577 & 6.584 & 5.477 & 5.413 \\
\hline $\begin{array}{l}\text { Tabungan Mudharabah } \\
\text { Savings }\end{array}$ & 40.758 & 50.637 & 57.442 & 65.642 & 71.743 \\
\hline Mudharabah Deposit & 106.266 & 122.022 & 137.377 & 142.008 & 146.243 \\
\hline
\end{tabular}

(Source: www.ojk.go.id)

From table 1 above, it can be seen that mudharabah savings and mudharabah deposits increase every year while mudharabah financing continues to decline. This condition is not in line with existing theory, which mentions the increasing number of mudharabah savings and mudharabah deposits are not followed by the development of mudharabah financing for Sharia Commercial Banks. When it happens continuously, it is certainly not good for the continuity of Sharia Commercial Banks in Indonesia.

The specific objective of this study is to determine the effect of mudharabah savings and mudharabah deposits on the mudharabah financing of Sharia Commercial Banks. The urgency of this research is to provide advice and input to the government, Sharia Banks, and stakeholders in order to get further performance improvement of Sharia Banks, especially Sharia Commercial Banks. The certain specifications related to this research scheme are discussions related to the research topic, which is the development of Sharia Commercial Banks in Indonesia

\section{Review of Litrature}

\subsection{Sharia Banking}

Sharia Banking means all concern due to Sharia Banks and Sharia Business Units, which includes institutions, business activities, methods and processes in carrying out their business activities. Islamic banking or Sharia banking is a banking system based on Islamic sharia principles. Islamic banking applies profit and risk sharing between fund providers (investors) and users of funds (entrepreneurs). Almost similar with conventional banking, the maximum profit level in sharia values must also be considered so that the parties involved can enjoy these benefits and when there is a loss, the parties involved also get burden on it. In addition, Sharia banks also manage zakat, and avoid any kinds of transactions related to goods that are haram and contain elements of maysir, gharar, and usury (Kasmir, 2014). Mudharabah principle, the customer acts as the owner of capital and the bank acts as the manager of capital (Nasib, 2019). 
Islamic banking is a bank institution that is managed with Islamic principles. The presence or establishment of Islamic banking, should depart from objective conditions with the existence of the people's decision or economic demands. Then, for an Islamic bank to survive and develop, its institutional management must be credible and the implementation of its business activities must be professional (Ariadin et al, 2020). The development of Islamic banks in Indonesia, of course, there must be support from quality human resource management. Because, it is not possible for a sharia bank to achieve success without qualified HR management. (Tarigan, 2020)

\subsection{Third Party Funds}

Third party funds are non-binding deposit funds which are entrusted by a customer from a third party neither from a bank in general nor a Sharia Business Unit (UUS) in the form of savings, time deposits, current accounts or other forms. The operational principles of sharia in collecting public funds are the principles of wadiah and mudharabah (Karim, 2013).

\subsection{Mudharabah Savings}

Mudharabah savings can be defined as savings owned by a customer whose deposit and withdrawal can be executed anytime, anywhere according to the previous agreement. This type of savings model does not provide interest benefit but benefit sharing (Muhammad, 2012). Furthermore, mudharabah savings are deposits which the withdrawals can only be made according to certain agreement terms, but cannot be withdrawn by check or any tools similar with it (Fauziyah, 2019).

\subsection{Mudharabah Deposits}

Mudharabah deposits are investment funds based on a mudharabah contract or other contracts that are not contradictory to sharia principles which withdrawals can only be made at a certain time based on an agreement between the deposit customer and the sharia bank and / or the Sharia Business Unit (UUS) (Septriyana, 2019).

\subsection{Mudharaba Financing}

In simple definition, financing is used to define funding activity made by financial institutions such as Sharia banks to customers. Financing in broadly definition means financing or spending funding that is issued to support planned investments, whether done personally or done by other people. According to Muhammad, financing is funding provided by a party to another party to support planned investments, whether done alone or by an institution (Muhammad, 2018).

\subsection{Conceptual Framework}

The conceptual framework in this study is illustrated by the chart below:

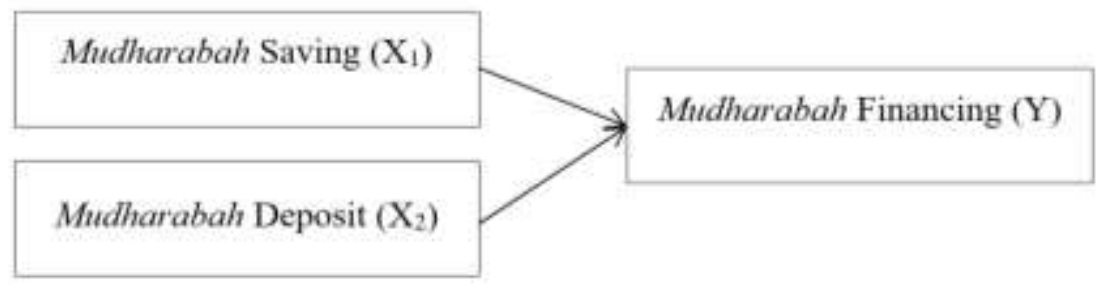

$\mathrm{X}_{1} \quad$ : Mudharabah Saving

$\mathrm{X}_{2} \quad$ : Mudharabah Deposit

Y : Mudharabah Financing 


\subsection{Research Hypothesis}

The hypotheses in this study are:

1. H0: There is no effect of Mudharabah Savings and Mudharabah Deposits on Mudharabah Financing for Sharia Commercial Banks.

2. Ha: There is an effect of Mudharabah Savings and Mudharabah Deposits on Mudharabah Financing for Sharia Commercial Banks

\section{Research Methods}

The approach in this research is a quantitative approach, because in measuring the data is using a numerical scale (numbers). The population in this study is the Statistics Sharia Bank (SPS), which includes statistics on mudharabah savings, mudharabah deposits, and mudharabah financing for Sharia Commercial Banks from January 2015 to December 2019 which comes from Statistics Sharia Bank (SPS) obtained from the Financial Services Authority website (OJK) with the link www.ojk.go.id. The sample in this study is the Statistics Sharia Bank (SPS) from 2015 to 2019 which comes from the Statistics Sharia Bank (SPS) obtained from the website of the Financial Services Authority (OJK) with the link www.ojk.go.id which is published monthly. In this study, the data used are secondary data in the form of time series from the Financial Services Authority (OJK) website www.ojk.go.id due to the amount of mudharabah financing, mudharabah savings, and mudharabah deposits. The data collection technique is to use documentation studies sourced from the 2015-2019 Statistics Sharia Bank (SPS), data obtained from the website of the Financial Services Authority (OJK) with the link www.ojk.go.id. The analysis of this research is carried out in some stages, they are: multiple linear regression, normality test, classic assumption test (multicollinearity test and autocorrelation test), statistical test (coefficient of determination (R2), statistical $F$ test, and statistical $t$ test).

\section{Results and Discussion}

\subsection{Classic Assumption Test}

The data normality test in this study is carried out with the help of the Normal Probability Plot statistical test tool (normal P-P Plot) for each variable. The Normal Probability Plot is done by comparing the observed values (observed normal) and the expected value from the normal (expected normal) distribution. If the distribution of plotting data (points) is around the diagonal line or follows the diagonal line, it can be concluded that the data is normally distributed.

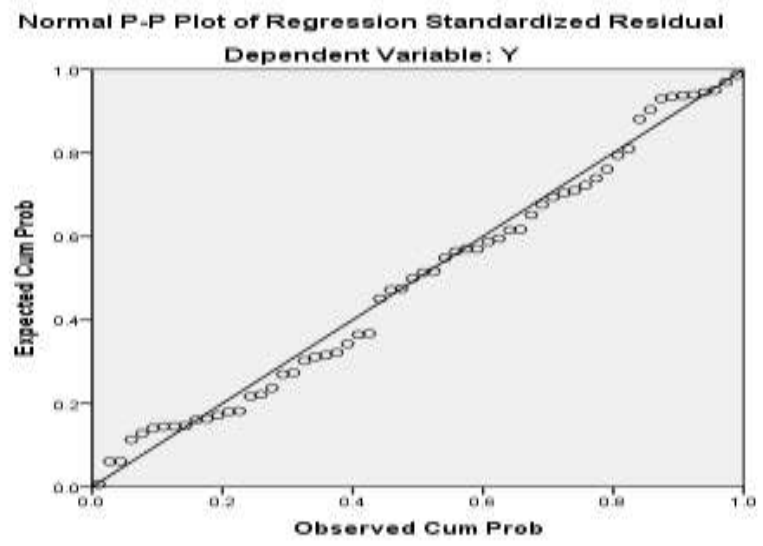

Source: Output Processed Data SPSS 20.0 in 2021 
The results of the P.P Plot (Normal Probability Plot) for the variables (X1), (X2) and (Y) show that the points spread around the diagonal line, and the distribution approaches the diagonal line, so this regression model is normally distributed.

\subsection{Multicollinearity Test}

Multicollinearity testing is carried out to explain the possibility of a relationship between one independent variable and another. To detect it, this study is conducted by looking at the Tolerance and Variance Inflation Factor (VIF) values for each independent variable provided with condition there are no multicollinearity symptoms, if the Tolerance value $>0.100$ and the VIF value $<10.00$.

Table 2. Multiconierity Test Results

Coefficients

\begin{tabular}{|c|c|c|c|c|c|c|c|}
\hline \multirow[b]{2}{*}{ Model } & \multicolumn{2}{|c|}{$\begin{array}{c}\text { Unstandardized } \\
\text { Coefficients }\end{array}$} & \multirow{2}{*}{$\begin{array}{c}\text { Standardized } \\
\text { Coefficients } \\
\text { Beta }\end{array}$} & & \multirow[b]{2}{*}{ Sig. } & \multicolumn{2}{|c|}{$\begin{array}{c}\text { Collinearity } \\
\text { Statistics }\end{array}$} \\
\hline & B & Std. Error & & & & Tolerance & VIF \\
\hline $1 \quad$ (Constant) & 11.508 & .426 & & 27.022 & .000 & & \\
\hline $\mathrm{X} 1$ & .020 & .008 & .286 & 2.686 & .009 & .117 & 8.512 \\
\hline $\mathrm{X} 2$ & -.140 & .012 & -1.225 & -11.506 & .000 & .117 & 8.512 \\
\hline
\end{tabular}

a. Dependent Variable: Y

Source: Output Processed Data SPSS 20.0 in 2021

Based on the table above, it can be seen that the Tolerance value at $\left(\mathrm{X}_{1}\right)$ is 0.117 while $\left(\mathrm{X}_{2}\right)$ is 0.117 with condition of the Tolerance value are $>0.100$, so it can be concluded that there are symptoms of multicollinearity. From the Variance Inflation Factor (VIF) value, the variable (X1) is 8.512 while the variable (X2) is 8.512 with condition for the VIF value are $<10.00$. So it can be concluded that this regression model has multicollinearity symptoms.

\subsection{Heteroscedasticity Test Results}

Heteroscedasticity test in the regression model is carried out to determine whether the regression model has an inequality of variants from the research residual value or not. To prove the presence or absence of heteroscedasticity disorders, it can be seen through the scatter diagram pattern (Scatterplot). If the Scatterplot forms a certain pattern, the regression experiences a heteroscedasticity disorder. In conversely, if the scatterplot does not form a certain pattern (spreads), and the points spread above and below the number 0 on the $\mathrm{Y}$ axis, then the regression does not experience heteroscedasticity disturbances. 


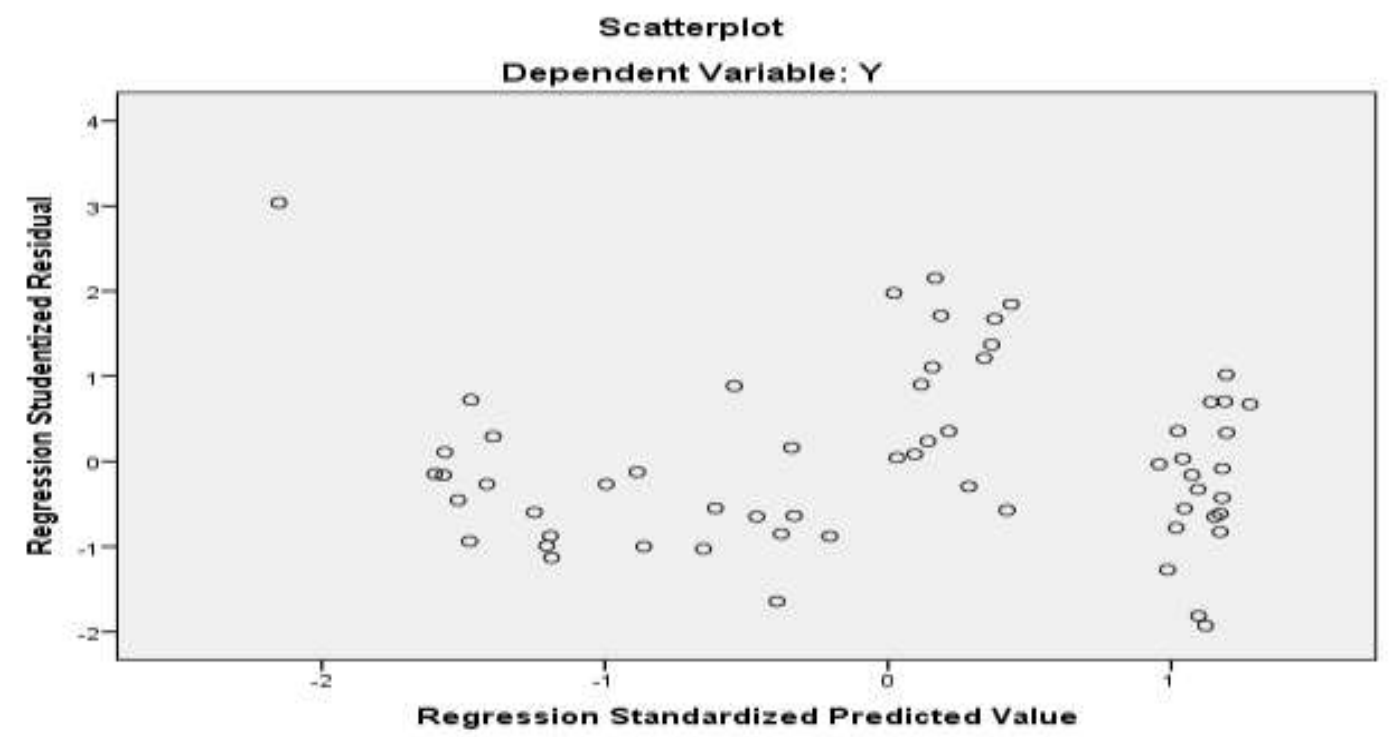

Source: Output Processed Data SPSS 20.0 in 2021

Figure 1. Heteroscedasticity Test Results

From the scatterplot graph above, it can be seen that the dots spread out randomly, do not form a clear pattern, and are scattered above and below the zero (0) on the $\mathrm{Y}$ axis. Therefore, it can be concluded that heteroscedasticity symptoms in the regression model in this study do not occur

\subsection{Multiple Linear Regression Analysis}

The results of the regression analysis can be seen in the table below:

Table 3. Results of Multiple Linear Regression Analysis

Coefficients a

\begin{tabular}{|c|c|c|c|c|c|c|c|}
\hline \multirow[b]{2}{*}{ Model } & \multicolumn{2}{|c|}{$\begin{array}{c}\text { Unstandardized } \\
\text { Coefficients }\end{array}$} & \multirow{2}{*}{$\begin{array}{c}\text { Standardized } \\
\text { Coefficients } \\
\text { Beta }\end{array}$} & \multirow[b]{2}{*}{$t$} & \multirow[b]{2}{*}{ Sig. } & \multicolumn{2}{|c|}{$\begin{array}{c}\text { Collinearity } \\
\text { Statistics }\end{array}$} \\
\hline & B & Std. Error & & & & Tolerance & VIF \\
\hline $1 \quad$ (Constant) & 11.508 & .426 & & 27.022 & .000 & & \\
\hline $\mathrm{X} 1$ & .020 & .008 & .286 & 2.686 & .009 & .117 & 8.512 \\
\hline $\mathrm{X} 2$ & -.140 & .012 & -1.225 & -11.506 & .000 & .117 & 8.512 \\
\hline
\end{tabular}

a. Dependent Variable: Y

Source: Calculation Result SPSS (Attached)

Based on table above, the multiple linear regression equation in this study is:

$$
\mathrm{Y}=11,508+0,020 \mathrm{X}_{1}-0,140 \mathrm{X}_{2}+\mathrm{e}
$$

The results can be seen from the following information:

1. In this regression model, the listed constant value is 11.508 which means that if the independent variables in the model are assumed to be zero, the average the variables outside the model will increase mudharabah financing by 11.508 billion or in other words if the variables of mudharabah savings and deposits are not increased, then mudharabah financing is 11.508 billion. 
2. The value of the regression coefficient b1 in this study is 0.020 , it means that when mudharabah savings increase one billion, it will increase mudharabah financing by 0.020 billion.

3. The value of the regression coefficient b2 in this study is -0.140 . It means that the mudharabah deposit variable is -0.140 which indicates that when mudharabah deposits increase one billion, it will reduce mudharabah financing by 0.140 billion.

\subsection{Partial Test (t test)}

The results of the first hypothesis test partially can be seen in the following table:

Table 4. t Test Results

Coefficients

\begin{tabular}{|c|c|c|c|c|c|c|c|}
\hline \multirow[b]{2}{*}{ Model } & \multicolumn{2}{|c|}{$\begin{array}{l}\text { Unstandardized } \\
\text { Coefficients }\end{array}$} & \multirow{2}{*}{$\begin{array}{c}\text { Standardized } \\
\text { Coefficients } \\
\text { Beta }\end{array}$} & \multirow[b]{2}{*}{$\mathrm{t}$} & \multirow[b]{2}{*}{ Sig. } & \multicolumn{2}{|c|}{$\begin{array}{c}\text { Collinearity } \\
\text { Statistics }\end{array}$} \\
\hline & $\mathrm{B}$ & Std. Error & & & & Tolerance & VIF \\
\hline $1 \quad$ (Constant) & 11.508 & .426 & & 27.022 & .000 & & \\
\hline $\mathrm{X} 1$ & .020 & .008 & .286 & 2.686 & .009 & .117 & 8.512 \\
\hline $\mathrm{X} 2$ & -.140 & .012 & -1.225 & -11.506 & .000 & .117 & 8.512 \\
\hline
\end{tabular}

a. Dependent Variable: Y

Source: Calculation Result SPSS (Attached)

Based on the table above, here are the results:

1. The significance value for the mudharabah savings variable (0.009) is smaller than $5 \%$ alpha $(0.05)$ or $\mathrm{t}$ count $=2.868>\mathrm{t}$ table 2.001. Based on the results obtained, $\mathrm{H} 0$ is rejected and $\mathrm{Ha}$ is accepted for the mudharabah savings variable. It means, partially the mudharabah savings variable has a positive and significant effect on the mudharabah financing of Sharia Commercial Banks.

2. The significance value for the mudharabah deposit variable $(0.000)$ is smaller than $5 \%$ alpha $(0.05)$ or $\mathrm{t}$ count $-11.506<\mathrm{t}$ table 2.001. Based on the results obtained, $\mathrm{Ha}$ is rejected and $\mathrm{HO}$ is accepted for the mudharabah deposit variable. It means, partially the mudharabah deposit variable has no effect on the mudharabah financing of Sharia Commercial Banks.

\subsection{Simultaneous Test (Test F)}

The results of the F test in this study can be seen in the table below:

Table 5. F Test Results ANOVAa

\begin{tabular}{|rl|r|r|r|r|r|}
\hline \multicolumn{2}{|l|}{ Model } & \multicolumn{1}{|c|}{$\begin{array}{c}\text { Sum of } \\
\text { Squares }\end{array}$} & df & \multicolumn{1}{c|}{$\begin{array}{c}\text { Mean } \\
\text { Square }\end{array}$} & F & Sig. \\
\hline 1 & Regression & 75.178 & 2 & 37.589 & 346.991 & $.000^{\mathrm{b}}$ \\
& Residual & 6.175 & 57 & .108 & & \\
& Total & 81.353 & 59 & & & \\
\hline
\end{tabular}

a. Dependent Variable: Y

b. Predictors: (Constant), X2, X1

Source: Calculation Result SPSS (Attached) 
In the regression test results in this study, it is known that the significance value is 0.000 . The required significance value of $\mathrm{F}$ is less than $5 \%$ or 0.05 or the value of Fcount $=$ 346.991> F table 3.16. It can be concluded that all the independent variables, namely mudharabah savings and mudharabah deposits have a positive and significant effect on the mudharabah financing of Sharia Commercial Banks.

\subsection{Coefficient of Determination (R2)}

The results of the determination test can be seen in the following table:

Table 6. The results of the determination coefficient test

$$
\text { Model Summary b }
$$

\begin{tabular}{|l|r|r|r|r|}
\hline Model & \multicolumn{1}{|c|}{$\mathrm{R}$} & R Square & \multicolumn{1}{c|}{$\begin{array}{c}\text { Adjusted } \mathrm{R} \\
\text { Square }\end{array}$} & Std. Error of the Estimate \\
\hline 1 & $.961^{\mathrm{a}}$ & .924 & .921 & .32913 \\
\hline
\end{tabular}

a. Predictors: (Constant), X2, X1

b. Dependent Variable: Y

Source: Output Processed Data SPSS 20.0

The correlation regression value is 0.961 , it means that the effect both of mudharabah savings and mudharabah deposits on mudharabah financing of PT. Delamibrands Charisma Clothing has contributed to a close and positive level. Then the adjusted R Square value (R2) is $0.921(92.1 \%)$. So it can be said that $92.1 \%$ of the variation in the dependent variable, namely mudharabah savings and mudharabah deposits in the model can explain the variable of Sharia Commercial Bank mudharabah financing, while the remaining $7.9 \%$ is influenced by other variables outside the model.

\subsection{The Effect of Mudharabah Savings on Mudharabah Financing}

The results of this study indicate that mudharabah savings have a positive and significant effect on mudharabah financing. This result can be proven from the value for the mudharabah savings variable (0.009) which is smaller than 5\% alpha (0.05) or t count $=2.868>\mathrm{t}$ table 2.001. The results of this study are in line with the results of research conducted by (Afifah, 2020)(Mardiana, 2018) which states that increasing mudharabah savings will be able to increase mudharabah costs.

\subsection{The Effect of Mudharabah Deposits on Mudrabah Financing}

The results of the research show that mudharabah deposits have no effect on mudharabah financing. It can be shown by the significance value for the mudharabah deposit variable (0.000) which is smaller than 5\% alpha (0.05) or t count $-11.506<\mathrm{t}$ table 2.001. The results of this study support the results of research conducted by (Fauziyah, 2019) (Cahyani, 2020) which states that mudharabah deposits have no effect on mudharabah financing. Then this research is not in line with the results of research (Septriyana, 2019)(Mawardi, 2019) which states that mudharabah deposits have a positive and significant effect on mudharabah financing. 


\subsection{The Effect of Mudharabah Savings and Mudharabah Deposits on Mudharabah Financing}

It is known that the significance value is 0.000 . Where the required significance value of $\mathrm{F}$ is less than $5 \%$ or 0.05 or the value of Fcount $=346.991>\mathrm{F}$ table 3.16. Thus, it can be concluded that all the independent variables which are mudharabah savings and mudharabah deposits have a positive and significant effect on the mudharabah financing of Sharia Commercial Banks. The results of this study support the results of previous research conducted by (Septriyana, 2019)(Cahyani, 2020)(Fitriani, 2020) which states that mudharabah savings and mudharabah deposits have a positive and significant effect on mudharabah financing.

\section{Conclusion}

Based on the results of the research, it can be taken the conclusion that partially only mudharabah savings have a positive and significant effect on mudharabah financing in Sharia Commercial Banks. While mudharabah deposits have no effect on the mudharabah financing of Sharia Commercial Banks. Furthermore, simultaneously the two independent variables, namely mudharabah savings and mudharabah deposits have a positive and significant effect on mudharabah financing for Sharia Commercial Banks.

\section{Thank-you note}

The writer would like to thank the Directorate of Research and Investigation and Community Service (DRPM) for giving the opportunity to the author to do this research. Research funding assistance that has been provided through research activities grants for novice lecturers research is very helpful for the implementation of this research. Furthermore, researcher also give appreciation to all parties who have helped a lot, especially in the preparation of this research report.

\section{References}

Afifah, S. (2020). Analisis Pengaruh Tabungan Mudharabah, Giro Mudharabah Dan Pembiayaan Bagi Hasil Terhadap Laba Bersih Pada Bank Muamalat Indonesia Periode 2016-2018. Skripsi. Universitas Islam Negeri Raden Intan Lampung.

Ariadin, et al. (2020). Shari'ah Compliance Rights in Implementation of Legal Principles on Shari'ah Banking. Budapest International Research and Critics Institute-Journal (BIRCI-Journal). P. 1530-1541.

Cahyani, G. U. (2020). Pengaruh Tabungan Mudharabah Dan Deposito Mudharabah Terhadap Bagi Hasil Mudharabah Pada PT Bank Syariah Mandiri Indonesia (Periode Juni 2017-Mei 2020). Institut Agama Islam Neheri Surakarta.

Fauziyah, A. (2019). Pengaruh Tabungan Mudharabah Dan Deposito Mudharabah Terhadap Pendapatan Bagi Hasil Mudharabah Pada Bank Maybank Syariah (Periode 2012-2014). Skripsi. Universitas Islam Negeri Sultan Maulana Hasanudin Banten.

Fitriani, D. A. (2020). Analisis Pengaruh Giro Wadi'ah Dan Tabungan Wadi'ah Terhadap Pembiayaan Mudharabah Pada PT. Bank Muamalat Indonesia Periode 2011- 2018. Skripsi. Universitas Islam Negeri Walisongo Semarang.

Karim, A. A. (2013). Bank Islam: Analisis Fikih dan Keuangan. Jakarta: Rajawali Press. Kasmir. (2014). Dasar-Dasar Perbankan Edisi Revisi. Jakarta: Rajawali Press. 
Mardiana, N. (2018). Pengaruh Tabungan Mudharabah Dan Pembiayaan Murabahah Terhadap Laba Operasional Pada PT. Bank Panin Syariah Tbk. Universitas Islam Negeri Sunan Gunung Djati.

Mawardi, A. M. C. (2019). Analisis Pengaruh Giro Wadiah, Tabungan Mudharobah Dan Deposito Mudharobah Terhadap Profitabilitas Bank Syariah Yang Terdaftar Di Bei. E-JRA, 08(02), 23-31.

Muhammad. (2018). Manajemen Bank Syariah Edisi Revisi Kedua. Yogyakarta: UPP STIM YKPN.

Nasib, R. A. I. L. (2019). Keuangan \& Perbankan. Bandung: CV. Sadari.

Septriyana, S. (2019). Pengaruh Deposito Mudharabahdan Ekuitas Terhadap Pembiayaan Mudharabah (Studi Pada Bank Umum Syariah Periode 2012-2018). Institut Agama Islam Negeri Ponorogo.

Tarigan, N. et al. (2020). The Effect of Employee Competence on Increasing Employee Motivation in Sumut Bank of Sharia Unit, North Sumatera. Budapest International Research and Critics Institute-Journal (BIRCI-Journal). P.858-867. 